perhaps too recondite topics: Steffensen (chromosomes and metal ions), Yamamoto (fertilization in fishes). Some other authors fail to consider the needs of the non-specialist although their subjects are of general importance; Schweiger (erythrocyte metabolism) and Ball (mitochondrial composition), for example, seem to me, as a non-biochemist, to be writing primarily for specialists. Here, editorial control appears to be inadequate, as also in Felts's excessively detailed and turgid treatment of bone implants in vivo, in Bertalanffy's superficial and uncritical review of cell renewal, and in Bessis's premature attempt to describe the electron microscopy of blood cells. Similarly, Wilbrandt should have been persuaded to expand into something more thorough his brief lecture on cation transport, originally delivered in 1960 and now reprinted, little changed, after two years. Nath on the cytochemistry of the Protozoa, however, gives sheer joy; he is off to a flying start with the statement that the work of the Oxford cytologists (and Nath) has "more or less solved the Golgi problem in Metazoa", and the pace thereafter never slackens.

The criticisms I have expressed reflect, inevitably, my personal prejudices and interests, but $I$ think few readers of these volumes will escape similar feelings, although perhaps with different foci of irritation. No cell biologist will find these volumes devoid of interest; few will want them on their own bookshelves. I feel regretfully that given rigorous editorial control the International Review of Cytology could be much more valuable.

T. VICKERS

\section{EXPLORING THE CELL}

General Cytochemical Methods

Vol. 2. Edited by Prof. J. F. Danielli. Pp. xi +297. (New York: Academic Press, Inc.; London: Academic Press, Inc. (London), Ltd., 1961.) 80s. net.

7 HIS is the second volume of a series edited by Prof. Danielli, and a general pattern is beginning to emerge. The individual articles are highly specialized, but they are all concerned with physical or chemical cytology and despite their apparent diversity the series as a whole possesses a degree of coherence often lacking in others of this nature. Certainly anyone working with cells would find it necessary to have at least some acquaintance with most of the topics discussed, if only to assess the value of work by other scientists.

The first article by Ross deals with immersion refractometry of living cells. It gives a useful account of how both phase contrast and interference microscopy can be used for measuring the solid concentration and dry mass of living cells.

The next three chapters give authoritative accounts of the Cartesian diver and related techniques. Zeuthen deals with the Cartesian diver balance, Holter with the standard diver and Zajicek and Zeuthen with the use of the ampulla diver for determining cholinesterase activity in single cells. The emphasis in these chapters is mainly practical, but examples of applications ranging from the growth of single amobæ to the quantitative estimation of cholinesterase in single bone marrow cells or parts of single neurones are discussed.

Daoust describes a method that may have widespread applications in the study of many intra-cellular enzymes. though the present article is restricted to deoxyribonuclease. A tissue section is covered by a thin film of gelatin containing an appropriate substrate. After a suitable exposure this film is stained to reveal areas attacked by the enzyme. The technique has many features in common with autoradiography.

McManus in his article on periodate oxidation techniques gives a good account of some aspects of carbohydrate histochemistry. Dimedone blocking. which is very useful for distinguishing between glycogen and other periodic acid-Schiff-positive substances, is not mentioned, and I believe that the use of saliva rather than amylase for removing glycogen may give misleading results in some cases.

The last two articles are concerned with aspects of protein histochemistry. Barnard discusses acylation and diazonium coupling and Maddy describes the use of fluoro-2 : 4-dinitrobenzene as a cytochemical reagent. These articles show how well-known chemical reactions can be adapted for histochemistry and indicate some of the special difficulties that may be encountered. It is clear that the day of the amateur in this field is passing, and future progress will depend on a thorough understanding of chemical theory and methods.

Altogether this is becoming a solid and satisfying series. Prof. Danielli is wise to avoid the pitfalls of annual publication. If he continues to bring out further volumes as necessary he will render a useful service to cytology.

R. Baren

\section{FRESH FRAMEWORKS FOR DEVELOPMENTAL ANALYSIS}

New Patterns in Genetics and Developments By Prof. C. H. Waddington. Columbia Biological Series, No. 21.) Pp. xiv $+271+24$ plates. (New York and London : Columbia University Press, 1962.) 80s., 10.00 dollars.

DROF. C. H. WADDINGTON is well known for his excursions into art, architecture and philo. sophy and his readiness to adopt notions and nomenclature from these fields into his home-ground of genetics and embryology. Embryologists cannot thank him for introducing more vocabulary into a subject already confused with foreign 'coinage', but they will have to admit that some of the ideas included in this new book cannot be expressed except in the special jargon in which they originated. The book, which is a transcription from lectures delivered in Columbia University in 1961, deals with developmental processes from the molecular level up to the multicellular and multi-organ levels of complexity. The 'new patterns' indicated in the title are patterns of thought, derived from biochemistry, microbial genetics, thermodynamics, statistics, architecture and even social science. Patterns of structure, revealed by means of the electron microscope, are also discussed: but it is the causes underlying them and the causal systems they represent, rather than any description of them in static terms, that occupy the author's attention.

Because of the inevitable time-lag before publication, Waddington's first chapter, dealing with molecular synthesis, now lacks freshness of impact. We have already read elsewhere much clearer, crisper accounts of enzyme induction and repression, of the 'operon' system for gene action proposed by Jacob and Monod, and of possible genetic coding mechanisms. However, this chapter is still useful in remind- 